\title{
Karyomorphological Studies in Three Populations of Solanum surattense, a Weed
}

\author{
R. N. Trivedi and A. K. Sinha ${ }^{1}$ \\ Cytogenetics Laboratory, Department of Botany, Magadh University, \\ Bodh-Gaya 824234, India
}

Accepted December 18, 1984

Solanum surattense Burm $\mathrm{f}$. described as non-tuberiferous and armed species by taxonomists, is a common weed growing throughout India. It is distributed at different longitude, latitude and altitude upto 2,300 metres (Sinha 1982). Cytogenetically this species is provided with a variety of characteristics. Cytologically, however, the species appears to be much less known; all available information is of preliminary nature dealing mainly with its chromosome counts (Bhaduri 1951, Fedorov 1974).

It has been discovered that the evolutionary development often involes alterations in the number and structure of the chromosomes which are the physical basis of the genetic system of a species. In the similar way, the performance of a population depends not only on the functional properties of the genes but also on the way in which the genes are distributed to the individual genotypes i.e., on the genetic structure of the population. Therefore, much can be known regarding the relation between the individuals of the species by a comparative study of the chromosomes with respect to their structure and about the chromosomal polymophism. The present communication is a detailed karyotypic account of three populations of this species from a biosystematic point of view.

\section{Materials and methods}

Materials for the present investigation include three populations of the species of the species Solanum surattense, the details of their locality and period of collection have been given in Table 1. The herbaria were identified from Botanical Suvery of India, Shibpur, Calcutta and the voucher specimens have been deposited to herbaria in the Department of Botany, Magadh University.

\section{Mitotic study}

For somatic chromosome studies, young and healthy root tips were pretreated with alpha bromonapthalene for 1 to 1-1/2 hours and were fixed in 1:3 acetoalcohol ( $5 \%$ ferric chloride was used as a mordant). Root tips were stained in acetocarmine and squashed in $45 \%$ acetic acid. The detailed structure of chromosomes was made out from enlarged photographs of temporary preparations. Total form (T.F.\%) has been calculated as:

\footnotetext{
1 Department of Botany, Jagjiwan College, Gaya-823003, India.
} 
Table 1. List of materials with locality and period of collection

\begin{tabular}{lclllc}
\hline \hline $\begin{array}{c}\text { Name of the } \\
\text { species }\end{array}$ & Populations & Locality & $\begin{array}{l}\text { Period of } \\
\text { collection }\end{array}$ & Temperature \\
\hline Solanum & (1) & Ss0777 & Bodh Gaya & 6 July, 1976 & $42^{\circ} \mathrm{C}$ \\
surattense & (2) $S s 1276$ & Gaya town & 2 December, 1976 & $26^{\circ} \mathrm{C}$ \\
Burm f. & (3) & Ss0478 & Jaipur & 24 April, 1978 & $41^{\circ} \mathrm{C}$ \\
\hline
\end{tabular}

$$
\frac{\text { sum total of small arm length }}{\text { total length of chromosomes }} \times 100
$$

given by Huziwara (1962).

\section{Observations}

\section{1) Population-Ss0777}

This population consisted of only two plants. They were growing by the side of a wall.

Somatic chromosome number was found to be $2 n=24$ (Fig. 1). From an analysis of detailed karyotype, it was found that five pairs of chromosomes were submedian while six pairs were median and one pair was of subterminal type. No chromosome with secondary constrictions was observed. Chromosome pairs have been represented in idiogram (Fig. 2) and the detailed chromosome measurements are summarized in Table 2.

\section{2) Population-Ss1276}

The population consisted of six plants which were growing scattered on roadsides.

Somatic chromosome number was found to be $2 n=24$ (Fig. 3). Chromosome varied in length from $1.175 \mu$ to $2.825 \mu$. There were five pairs of median, four pairs of submedian, two pairs of subterminal and one pair of terminal type of chromosomes. No SAT chromosomes were observed. Chromosome pairs have been represented in the idiogram (Fig. 4) and the detailed chromosome measurements are summarized in Table 2.

\section{3) Population-Ss0478}

Plants of this population had larger leaves as compared to the above two localities. The population was a small one.

Somatic chromosome number observed from root tip cells was $2 n=24$ (Fig. 5). Length of chromosome varied from $1.30 \mu$ to $2.66 \mu$. The primary constrictions in the chromosome were median, submedian and terminal. Detailed karyotypic studies revealed that there were five pairs of submedian, six pairs of median and one

Figs. 1-6. 1, mitotic chromosomes at metaphase of Ss0777 population showing twenty-four chromosomes. $\times 1400$. 2, idiogram of mitotic chromosomes. 3, mitotic chromosomes at metaphase of Ss 1276 population showing twenty-four chromosomes. $\times 1400,4$, idiogram of mitotic chromosomes. 5, mitotic chromosomes at metaphase of $S s 0478$ population showing twenty-four chromosomes. $\times 2500$. 6 , idiogram of mitotic chromosomes. 


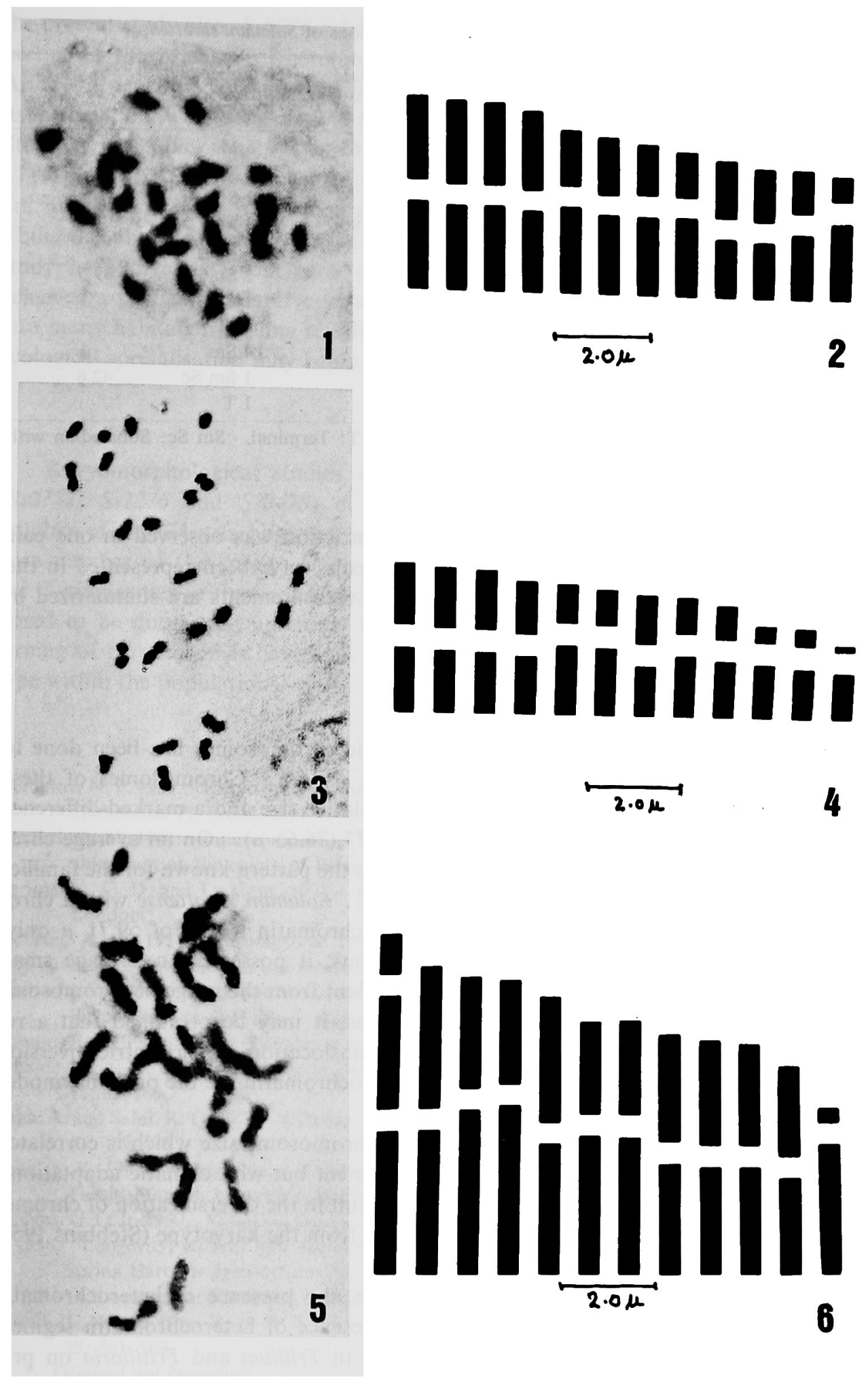


Table 2. Chromosome of different populations of Solanum surattense

\begin{tabular}{|c|c|c|c|c|c|}
\hline Populations & $2 n$ & $\begin{array}{c}\text { Range of } \\
\text { chromosome } \\
\text { length in } \mu\end{array}$ & $\begin{array}{c}\text { Total } \\
\text { chromosome } \\
\text { length in } \mu\end{array}$ & $\begin{array}{c}\text { Number of } \\
\text { chromosome } \\
\text { pairs }\end{array}$ & T. F. $\%$ \\
\hline Ss0777 & 24 & 2.425 to 4.0 & 76.65 & $\begin{array}{l}6 \mathrm{M} \\
5 \mathrm{Sm} \\
1 \mathrm{St}\end{array}$ & 43.25 \\
\hline Ss 1276 & 24 & 1.175 to 2.825 & 51.90 & $\begin{array}{l}5 \mathrm{M} \\
4 \mathrm{Sm} \\
2 \mathrm{St} \\
1 \mathrm{~T}\end{array}$ & 39.5 \\
\hline Ss0478 & 24 & 1.30 to 2.66 & 50.58 & $\begin{array}{l}6 \mathrm{M} \\
4 \mathrm{Sm} \\
1 \mathrm{Sm} \mathrm{Sc} \\
1 \mathrm{~T}\end{array}$ & 42.6 \\
\hline
\end{tabular}

M: Median. Sm: Submedian. St: Sub-terminal. T: Terminal. Sm Sc: Submedian with secondary constriction.

pair of terminal chromosomes. Secondary constriction was observed in one pair of submedian chromosome. The chromosome pairs have been represented in the idiogram (Fig. 6) and the detailed chromosome measurements are summarized in Table 2.

\section{Discussion}

The critical study of morphology of somatic chromosomes has been done in three populations namely: Ss0777, Ss 1276 and Ss0478. Chromosomes of these populations varied in their absolute as well as relative size and a marked difference was noted in the total chromatin length of $S s 0777(76.65 \mu)$. On an average chromosomes are small in size and the findings fit into the pattern known for the families of evolutionary advanced status (Stebbins 1971). Solanum surattense with a chromosome number $2 n=24$ has the average total chromatin length of $59.71 \mu$ only. This indicates that in almost all the populations, it possesses an average small chromosome except in Ss0777. This is also evident from the range of chromosome length in different populations (Table 2). Thus, it may be presumed that a repatterning of chromosome involving unequal translocation or pericentric inversion in addition to elimination or acquisition of heterochromatin are the probable modes of diversification among the karyotypes.

Avdulov (1931) pointed out variations in chromosome size which is correlated not with phylogenetic primitiveness or advancement but with climatic adaptations. Adaptations to temperature and altitude may result in the diversification of chromosome size by loss or addition of inert chromatin from the karyotype (Stebbins 1950, Trivedi and Roy 1970, Singh and Saini. 1971).

In the three populations mentioned above, the presence of heterochromatin can bring about differences in length. The presence of heterochromatin segment along the chromosome arm has been detected in Trillium and Fritillaria on prolonged treatment of cold in the somatic cells (Darlington and La Cour 1972). In 
the present study also, $\mathrm{Ss} 0777$ exhibits the tolerance of high temperature which may be due to the presence of heterochromatin segments along the chromosome arm. Although genetic significance of heterochromatin is yet to be clearly understood, its association with gene action has long been recognised (Lima-de-Faria 1956, Stebbins 1958, Jackson 1971).

Total form values mentioned earlier indicate that the crhomosomes of $\mathrm{Ss} 0777$ are more symmetrical as compared to the chromosomes of $S s 1276$ and $S s 0478$. Thus, the above discussions have led to the findings that the populations under study have diverged from each other. Once a chromosomal readjustment has achieved a particular adaptive value, the evolutionary line bearing it can radiate it into many habitats including relatively stable ones, thus a new cycle of genetic and ecological specialisation may begin.

\section{Summary}

Karyomorphological studies were carried out in three natural populations (Ss0777, Ss1276 and Ss0478) of Solanum surattense. A somatic chromosome number of $2 n=24$ was observed in all the three populations establishing that the base number of the species is $x=12$. Detailed karyotypic studies have revealed the dissimilarities in the length and quality of chromosomes which have been supposed to be due to asymmetrical karyotype. The climatic conditions and repatterning of chromosomes have also been accounted for the diversification of karyotype within the populations.

\section{References}

*Avdulov, N. P. 1931. Karyo-systemische Untersuchung der Familie Gramineen. Bull. Appl. Bot. Genet. and Pl. Breed. 43.

Bhaduri, P. N. 1951. Interrelationship of non-tuberiferous species of Salanum with some consideration on the origin of Brinjal. Ind. J. Genet. and Pl. Breed. 11: 75-82.

Darlington, C. D. and La Cour, 1972. Handling of Chromosomes. G. Allen and Unwin Ltd., London.

Fedorov, A. A. 1974. Chromosome Numbers of Flowering Plants. Reprint by Otto Koeltz Science Publishers, n-624 Koenigstein/West Germany.

Huziwara, Y. 1962. Karyotype analysed in some genera of Compositae VIII. Further studies on the chromosome of Aster. Amer. J. Bot. 49: 116-119.

Jackson, R. C. 1971. The karyotype in systematics. Ann. Rev. and Syst. 2: 327-368.

Lima-de-Faria, A. 1956. The role of the kinetochore in chromosome organisation. Hereditas 42: $85-160$.

Singh, A. and Saini, R. G. 1971. Cytological studies on triploid Trigonella corniculata L. Genetica 42: 469-476.

Sinha, A. K. 1982. Cytogenetical studies of Solanum surattense and some related species. Ph. D. Thesis, Magadh University, Bodh-Gaya.

Stebbins, G. L. Jr. 1950. Variation and Evolution in Plants. Columbia University Press, New York.

- 1958. Longevity, habitat and the release of genetic variability in the higher plants. Cold Spring Harbour Symposium Quant. Biol. 23: 365-378.

- 1971. Chromosomal Evolution in Higher Plants. Edward Arnold Ltd., London.

Trivedi, R. N. and Roy, R. P. 1970. Cytogenetical studies in Cucumis and Citrullus. Cytologia 35: $561-569$.

* Original not consulted. 